SHORT REPORT

\title{
Core needle biopsy in male breast lesions
}

\section{P J Westenend}

J Clin Pathol 2003;56:863-865

\begin{abstract}
Aims: To describe results of needle core biopsies of the male breast.

Methods: Needle core biopsies from male breasts and corresponding histological follow up data were retrieved from pathology computer files. For those biopsies with no histological follow up data, the nationwide pathology computer files were consulted.

Results: Twenty six core biopsies of male breasts were performed from 1993 until the end of 2002. All patients had unilateral lesions and were between 20 and 88 years old. In seven patients, core biopsy results were confirmed in the excision specimen. In one patient, the core biopsy diagnosis of cancer was confirmed in another hospital. In 17 patients with a benign core biopsy that was not excised in one of the hospitals served by this laboratory, the nationwide pathology computer files did not retrieve a missed malignancy. One patient with cancer in a core biopsy did not receive surgery because of old age. Core biopsy or aspiration cytology was not used in six of 19 men with cancer.

Conclusions: Core biopsy of the male breast is a reliable preoperative diagnostic procedure, which should be used more often because it can help to avoid unnecessary surgery and in planning surgery for cancer.
\end{abstract}

$\mathrm{T}$ he importance of a preoperative diagnosis in the assessment of breast lesions in women is widely accepted. This preoperative diagnosis is achieved using a multidisciplinary approach by surgeons, radiologists, and pathologists-the so called triple test. The pathological diagnosis is achieved by the use of fine needle aspiration cytology (FNAC) and, since the introduction of spring loaded biopsy guns, also by core biopsy. The advantages for women with cancer are that the optimal treatment can be planned and discussed, and for those with benign lesions unnecessary operations can be avoided.

\section{"A preoperative pathological diagnosis can be as desirable in men as in women"}

The situation in men seems to be different, with a preoperative pathological diagnosis being made in only a limited number of men. ${ }^{1}$ Nevertheless, a preoperative pathological diagnosis can be as desirable in men as in women-for example, sentinel lymph node biopsies can also be performed in men with breast cancer. ${ }^{2}$ One of the reasons that a preoperative pathological diagnosis is not achieved could be that the incidence of breast cancer in men is low, and therefore the diagnosis is not considered. In the Netherlands, the incidence of male breast cancer is 0.8 / 100000 person years, as opposed to $121.3 / 100000$ person years in women (Dutch cancer registry 1995). In addition, the preoperative diagnosis of male breast lesions has received little attention-only a limited number of series of FNAC of the male breast have been reported. ${ }^{13-9}$ To the best of our knowledge, results of core biopsies of the male breast with spring loaded biopsy guns have not been reported. Here, we report our preliminary results with this technique.

\section{PATIENTS AND METHODS}

Our pathology service works for several community hospitals in the area. Core biopsy of the breast with spring loaded biopsy guns was first introduced at the end of 1993. The first biopsy of a male breast was also performed in 1993. All records of male patients undergoing core biopsy of the breast between 1993 and the end of 2002 were retrieved from our pathology computer files. Histological follow up of these core biopsies was obtained from the same files and correlated with these biopsies. No revision of the core biopsies was performed. For specimens without histological follow up in our own files, the nationwide pathology computer files were consulted. One patient was treated for his breast disease at another hospital and we contacted the department of pathology for follow up data.

\section{RESULTS}

In total, 26 core biopsies of male breasts were performed from 1993 until the end of 2002. All patients presented with unilateral lesions. Patients were between 20 and 88 years of age. Seven different surgeons and three radiologists obtained biopsies and each physician contributed one to five cases to our study. All surgeons and radiologists were experienced in taking core biopsies from female breasts. The number of cores taken for each patient varied between one and four. Thirteen different pathologists reviewed the slides, and no biopsies were regarded as inadequate. In seven patients, a core biopsy was performed after an inconclusive FNAC. Table 1 summarises the results from those biopsies with histological follow up, and all core biopsy results were confirmed in the excision specimen.

Table 2 provides the results of those biopsies without histological follow up in our department. Histological follow up was also not available for these patients after consulting the nationwide pathology computer files and therefore the follow up time is given. The time since the diagnosis was between five and 94 months. We assume that we missed no cancers, at least in those patients with a follow up time of more than one year. One patient with an invasive ductal carcinoma (patient 2) did not receive surgical treatment because of old age. Another patient with a small cell carcinoma (patient 21) was transferred to an academic hospital for treatment. The core biopsy was revised at the pathology department and the diagnosis was confirmed. No further excision of the breast lesion was performed.

During our study period, we received 156 FNAC specimens from male breasts. In the same period, we received 401 excision specimens from male breasts and diagnosed 19 malignancies, including two metastatic melanomas and one malignant lymphoma. Of these malignancies, four were diagnosed by core needle biopsy and nine were diagnosed 


\begin{tabular}{|c|c|c|c|c|c|}
\hline $\begin{array}{l}\text { Patient } \\
\text { number }\end{array}$ & $\begin{array}{l}\text { Patient age } \\
\text { (years) }\end{array}$ & $\begin{array}{l}\text { Biopsy } \\
\text { year }\end{array}$ & $\begin{array}{l}\text { FNAC before } \\
\text { biopsy }\end{array}$ & $\begin{array}{l}\text { Biopsy } \\
\text { diagnosis }\end{array}$ & $\begin{array}{l}\text { Excision } \\
\text { diagnosis }\end{array}$ \\
\hline 1 & 60 & 1993 & C4 & Benign & Gynaecomastia \\
\hline 5 & 65 & 1997 & & Carcinoma & Carcinoma \\
\hline 6 & 44 & 1997 & $\mathrm{Cl}$ & Gynaecomastia & Gynaecomastia \\
\hline 7 & 62 & 1998 & & Carcinoma & Carcinoma \\
\hline 15 & 74 & 2000 & $\mathrm{Cl}$ & Carcinoma & Carcinoma \\
\hline 19 & 73 & 2001 & & Carcinoma & Carcinoma \\
\hline 25 & 47 & 2002 & C3 & Benign & Gynaecomastia \\
\hline
\end{tabular}

with FNAC, leaving six malignancies without a preoperative diagnosis.

\section{DISCUSSION}

Our present study shows that core biopsy of male breast lesions with a spring loaded biopsy gun is a reliable method for achieving a preoperative diagnosis. For those biopsies with histological follow up, the diagnosis was confirmed in the excision specimen. The biopsies without histological follow up included two cases with carcinoma. In one of these cases, the diagnosis of small cell carcinoma was confirmed by independent review at the department of pathology of an academic hospital. The other patient did not receive surgery because of old age. Other biopsies without histological follow up were all benign and histological follow up was also not available in the nationwide pathology computer files. We assume that the follow up time is long enough to find cancers that were possibly missed.

\section{"Of the 17 men with a diagnosis of benign or gynaeco- mastia, only three underwent surgery, which suggests that core biopsy was successful in avoiding 14 operations"}

The number of cancers in this small series is relatively high, which no doubt reflects the selection of patients for this diagnostic procedure. Nevertheless, in the study period, six of 19 men with breast cancer in our files did not undergo an FNAC or core biopsy as a preoperative diagnostic procedure. All malignancies were in older men presenting with a unilateral lesion.
FNAC of the male breast has been more widely studied, and a high sensitivity, high specificity, and almost a 100\% positive predictive value for the diagnosis of malignancy have been demonstrated. ${ }^{13-9}$ The most important pitfall that has been reported for FNAC of the male breast is overdiagnosis of florid hyperplasia in gynaecomastia. This problem has been dealt with in case reports and some series, and the criteria to distinguish these lesions from carcinoma have been described. ${ }^{10-12}$ Consequently, this does not seem to be a major problem because only a limited number of overdiagnoses have been reported from institutions that have some experience with FNAC of the male breast. ${ }^{13-9}$ Nevertheless, hyperplasia in gynaecomastia was the reason that one FNAC was interpreted as suspicious (patient 1). A core biopsy showed gynaecomastia, which was confirmed in the excision specimen. At that time, we had only limited experience with FNAC of the breast, male or female. This reflects the fact that it will probably be easier to recognise florid hyperplasia in gynaecomastia in core biopsies than in FNAC by pathologists who have little experience with breast cytology. However, our results with female breast lesions suggest that equally good results can be obtained with FNAC and core biopsy by pathologists experienced in FNAC. ${ }^{13}$

Interestingly, although the numbers are small, of the 17 men with a diagnosis of benign or gynaecomastia, only three underwent surgery, which suggests that core biopsy was successful in avoiding 14 operations. We have previously reported a reduction in the number of operations for benign lesions with the use of FNAC. ${ }^{1}$

In conclusion, these data demonstrate that core biopsy of the male breast is a reliable, but too often neglected,

\begin{tabular}{|c|c|c|c|c|c|}
\hline $\begin{array}{l}\text { Patient } \\
\text { number }\end{array}$ & $\begin{array}{l}\text { Patient age } \\
\text { (years) }\end{array}$ & $\begin{array}{l}\text { Biopsy } \\
\text { year }\end{array}$ & $\begin{array}{l}\text { FNAC before } \\
\text { biopsy }\end{array}$ & $\begin{array}{l}\text { Biopsy } \\
\text { diagnosis }\end{array}$ & $\begin{array}{l}\text { Follow up time } \\
\text { (months) }\end{array}$ \\
\hline 2 & 80 & 1995 & & Carcinoma* & 94 \\
\hline 3 & 33 & 1996 & & Benign & 84 \\
\hline 4 & 82 & 1996 & C3 & Benign & 82 \\
\hline 8 & 70 & 1998 & & Benign & 55 \\
\hline 9 & 81 & 1998 & C3 & Gynaecomastia & 54 \\
\hline 10 & 73 & 1999 & & Gynaecomastia & 50 \\
\hline 11 & 72 & 1999 & & Gynaecomastia & 49 \\
\hline 12 & 62 & 1999 & & Gynaecomastia & 45 \\
\hline 13 & 20 & 1999 & & Gynaecomastia & 42 \\
\hline 14 & 73 & 1999 & & Gynaecomastia & 40 \\
\hline 16 & 77 & 2000 & $\mathrm{Cl}$ & Benign & 34 \\
\hline 17 & 88 & 2000 & & Gynaecomastia & 34 \\
\hline 18 & 69 & 2000 & & Gynaecomastia & 30 \\
\hline 20 & 58 & 2001 & & Small cell carcinoma† & 25 \\
\hline 21 & 63 & 2001 & & Gynaecomastia & 23 \\
\hline 22 & 71 & 2001 & & Gynaecomastia & 20 \\
\hline 23 & 66 & 2002 & & Gynaecomastia & 16 \\
\hline 24 & 35 & 2002 & & Benign & 7 \\
\hline 26 & 76 & 2002 & & Gynaecomastia & 5 \\
\hline
\end{tabular}




\section{Take home messages}

- Although often neglected, core biopsy of the male breast is a reliable preoperative diagnostic procedure

- Core biopsy or fine needle aspiration cytology should be performed more often because they can help to avoid unnecessary operations and can help in the planning of operations for cancer (such as sentinel lymph node biopsies)

- The preferred method is yet to be determined, but will also be dependent on the local situation, such as experience in performing these procedures

preoperative diagnostic procedure. Core biopsy or FNAC should be used more often because these procedures can help to avoid unnecessary operations and can help in the planning of operations for cancer-for example, sentinel lymph node biopsies can also be performed in men with breast cancer. ${ }^{2}$ Which method is to be preferred remains to be determined, but is also dependent on the local situation, such as experience in performing these procedures and the availability of pathologists trained in cytology.

Correspondence to: Dr P J Westenend, Pathologisch Laboratorium voor Dordrecht en omstreken, Laan van Londen 1800, 3317 DA, Dordrecht, The Netherlands; pwestenend@paldordt.com

Accepted for publication 31 May 2003

\section{REFERENCES}

1 Westenend PJ, Jobse C. Evaluation of fine needle aspiration cytology of breast masses in males. Cancer 2002;96:101-4.

2 Port ER, Fey JV, Cody HSIII, Borgen PI. Sentinel lymph node biopsy in patients with male breast carcinoma. Cancer 2001;91:319-23.

3 Gupta RK, Naran S, Simpson J. The role of fine needle aspiration cytology (FNAC) in the diagnosis of breast masses in males. Eur J Surg Oncol 1988;14:317-20.

4 Gupta RK, Naran S, Dowle CS, et al. The diagnostic impact of needle aspiration cytology of the breast on clinical decision making with an emphasis on the aspiration cytodiagnosis of the male breast. Diagn Cytopathol 1991;7:637-9

5 Sneige N, Holder PD, Katz RL, et al. Fine-needle aspiration cytology of the male breast in a cancer center. Diagn Cytopathol 1993;9:691-7.

6 Das DK, Junaid TA, Mathews SB, et al. Fine needle aspiration cytology diagnosis of male breast lesions. A study of 185 cases. Acta Cytol 1995;39:870-6.

7 Lilleng R, Paksoy N, Vural G, et al. Assessment of fine needle aspiration cytology and histopathology for diagnosing male breast masses. Acta Cytol 1995:39:877-81.

8 Vetto J, Schmidt VJ, Pommier R, et al. Accurate and cost-effective evaluation of breast masses in males. Am J Surg 1998;175:383-7.

9 Joshi A, Kapila K, Verma K. Fine needle aspiration cytology in the management of male breast masses. Nineteen years of experience. Acta Cytol 1999;43:334-8.

10 Russin VL, Lachowicz C, Kline TS. Male breast lesions: gynaecomastia and its distinction from carcinoma by aspiration biopsy cytology. Diagn Cytopathol 1989:5:243-7.

11 Martin-Bates E, Krausz T, Philips I. Evaluation of fine needle aspiration cytology of the male breast for the evaluation of gynaecomastia. Cytopathology 1990;1:79-85.

12 Amrikachi M, Green LK, Rone R, et al. Gynecomastia. Cytologic features and diagnostic piffals in fine needle aspirates. Acta Cytol 2001;45: 948-52.

13 Westenend PJ, Sever AR, Beekman-de Volder HJC, et al. A comparison of aspiration cytology and core needle biopsy in the evaluation of breast lesions. Cancer 2001;93:146-50.

\section{$\mathrm{ECHO}$}

Immunohistochemical expression patterns differ in recurrent and initial glioblastoma multiforme

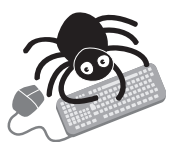

Please visit the Journal of Clinical Pathology website [www. jclinpath.com] for a link to the full text of this article.
There are significant differences in the expression patterns of the tumour suppressor gene p53, the cellular oncogene mdm2, epidermal growth factor receptor (EGFR) and the msh2 protein (part of the DNA mismatch repair system) in initial, as opposed to recurrent, glioblastoma multiforme. In particular, msh2 expressions may be affected by chemotherapy.

Twenty six adult patients were followed up whose tumour had been totally resected, 7 of whom were operated on for recurrence. Twenty three died at a mean of 532 days from diagnosis, while the mean progression free interval survival time was 204 days.

Recurrent lesions were characterised by reduced expression of $\mathrm{p} 53$ and msh2 while the numbers of mdm2, EGFR and msh2 positive specimens were reduced. The investigators suggest three possible reasons for reduced immunostaining: the antibody used in the study might not detect differentially expressed proteins; the expression level might actually decrease; or recurrent glioblastoma multiforme might represent a tumour stage of generally reduced protein expression caused by further dedifferrentiation.

Immunohistochemical findings showed no association with survival. However, chemotherapy (mainly cisplatin/tamoxifen) was associated with reduced msh2 expression.

A Journal of Neurology, Neurosurgery, and Psychiatry 2003;74:779-783. 